ARTICLE

Received 10 Apr 2017 | Accepted 19 Jun 2017 | Published 1 Aug 2017

\title{
The unemployable and the generic: rethinking the commons in the communist hypothesis
}

Gabriel Tupinambá1

\begin{abstract}
One of the main points of contention in the current debates surrounding Marxism has been the problem of finding a concrete substrate, which would orient the recuperation of the communist political strategy. Are there impasses in our contemporary society which justify the use of such a polemical notion as communism? Most authors currently involved with this debate agree that it is the problem of the "commons" under capitalism, which calls for a new theory and practice of communism. Where they disagree is on what the "commons" are and on how they exist within capitalism itself. The present contribution seeks to intervene on this debate and spell out the categorial recomposition of some fundamental aspects of Marxist critique of political economy implicitly at stake in Slavoj Žižek's theorization of the "antagonisms of the common". Taking up the insight of Antonio Negri and Michael Hardt concerning the new centrality of the enclosure of the commons in contemporary capitalism, Žižek has developed an alternative-more sober-view of the structural subsumption of these common spaces to the dynamics of Capital, where the very communal dimension of these domains only appear as common after they have been privatized. To extract the consequences of this assertion, we will first reconstruct the Marxist theory of enclosures in a comparative reading of the first volume of Capital and Karl Polanyi's classic The Great Transformation. This will lead us to a broader discussion of the contemporary transformations in capitalism, with a focus on the crisis of value as primarily sustained by absolute surplus-value extraction. With an understanding of the idea of the commons and a historical background of our current predicament, we will be in position to follow Antonio Negri's reading of how the enclosure of the commons leads to a new communist strategy and also to criticize it, using Slavoj Zizek's alternative understanding of our contemporary social antagonisms. Following through Zizek's reading of the logic of enclosures, we come to the conclusion that, first, unemployment has the structure of an enclosure, one which is responsible for the very form of the work commodity-as it was already suggested by Fredric Jameson and others-and, second, that, from a certain philosophical perspective shared by thinkers such as Zizek and Badiou, this realization can lead us to an innovative recuperation of the Marxist theory of "generic being", proposed by Marx in his Manuscripts of 1844.
\end{abstract}

\footnotetext{
${ }^{1}$ History Department, Pontifícia Univerdidade Católica, Rio de Janeiro, Brazil Correspondence: (e-mail: gabrieltupinamba@mac.com)
} 


\section{The ideas of communism}

lain Badiou introduced a great deal of clarity into the debate over how to critically assess the history of radical emancipatory politics in the XXth century by distinguishing three different dimensions of egalitarian political projects (Badiou, 2010): the communist hypothesis-a general and unlocalized commitment to the principle of equality-the idea of communism-different and situated formulations of this principle, articulated under concrete historical constraints-and the communist experiments-political sequences which put these different "incarnations" of the communist idea to the test, producing lasting examples and challenges for those who might seek to reformulate the hypothesis under new historical conditions later on.

We could schematize these complementary points of view as depicted in Fig. 1.

The affirmative hypothesis of communism is thus a statement that is totally devoid of concrete content, a purely philosophical defense of the possibility of thinking justice. The hypothesis as such says nothing of the historical existence of real equality, nor of a concept of equality with which we could evaluate particular historical sequences. Only an idea can turn this wager into a formulation which, being woven out of concrete reality, articulated within the limits of a given historical moment, would allow us to even ask if social equality, under such and such conditions, has taken place or not (Badiou, 2010: 258).

For example: what Marx and Engels called "critical-utopian socialism", 1 the socialism championed by Saint-Simon, Robert Owens or Charles Fourier, was precisely such an idea. It was by considering the brute social reality of early capitalism that these political thinkers defended that another sort of communal life was possible, unlike both the communities organized under decaying feudal rule and the emerging "civilized" world of the bourgeois cities. Serving themselves of the philosophical worldview of the times, which recognized in man a promethean force capable of conjuring up a different future for itself, these different thinkers envisioned the creation of a space subtracted from the blind capitalist drive-an $u$-topia, in a very tangible sense-where the hypothesis of political equality was articulated as the collective strive to organize, both socially and economically, a selfsustaining community. Fourier's phalansteries (Fourier, 2007), for instance, spread across Europe and the Americas, sought to put this formulation to the test, creating several isolated communities, with varying degrees of duration and social stability.
What all these experiments have in common, as the authors of the Communist Manifesto remind us, is that, due to "the undeveloped state of the proletariat, as well as to the absence of the economic conditions for its emancipation" (Marx and Engels, 1848: 32) at the time, the concrete determinations of their concept of equality came from either the historical past or from religion and morality. Therefore, these "times of universal excitement, when feudal society was being overthrown" gave rise to an idea of communism based on ethical communal values, rather than on the "material conditions" increasingly determined by the capitalist mode of production itself (1848: 29).

The analysis of utopian socialism presented in the Communist Manifesto is itself locatable within our schema-after all, there are two possible ways one can respond to the failure of a communist experiment: taking it either as further proof that there can be no such thing as an egalitarian society, or as further conditions which must be critically taken into account by any attempts to turn the communist hypothesis into a new determined idea. Engels would later term their own reformulation of the communist hypothesis the idea of "scientific socialism" (Engels, 2001), and we can see that this new idea answers both to the affirmative declaration that, against all odds, real equality is in fact possible under a given set of historical conditions-namely, the fully developed capitalist world-and to the negative assessment of previous communist experiments, which, from an analysis based on a "scientific" and "objective" critique of political economy, failed for believing that both the agents and the resources for socialism would have an origin or place outside of the capitalist system.

As the critical assessment of how many different forms the idea of communism took during the last century is far from a settled debate (Žižek and Douzinas, 2010; Žižek and Badiou, 2013; Bosteels, 2014; Žižek and Taek-Gwang Lee, 2016), we leave this exercise open as a proof of this model's usefulness, only noting that the idea, experiments and failures of "scientific socialism" could be easily inscribed in the critical cycle we have proposed here. Instead, let us shift our attention to the immediate present, as Badiou's critical model also allows us to locate our current predicament within the history of the communist hypothesis.

\section{The idea of the commons}

In recent years, the political problem of the "commons" has offered itself as a historical determination capable of igniting a

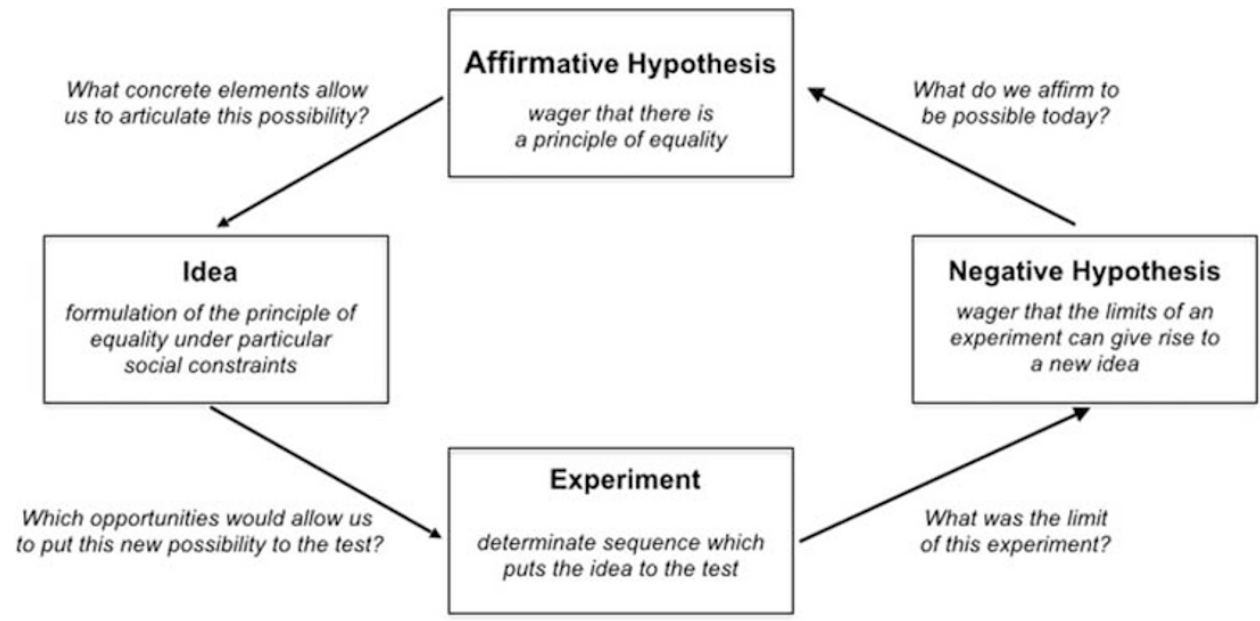

Figure 1 | Badiou's schematization. This is Alain Badiou's schematization of the distinction between a hypothesis, an idea, an experiment and the critical assessment of the experiment, or, the negative hypothesis that the experiment can lead to a new idea for an hypothesis. 
new formulation of the communist idea. There have been, in fact, two interrelated movements leading to this: on the one hand, a philosophical tendency has emerged, specially among continental thinkers, seeking to elaborate a new theory of equality, one in which thinking what is common among certain elements does not require these elements to be equivalent or identical in any sense, ${ }^{2}$ while, on the other hand, new critical analyses of our economic and political predicament have highlighted the continuing importance of so-called "primitive accumulation" in the era of financial capitalism (Fumagalli and Mezzadra, 2010) - that is, the centrality of the "enclosure of the commons" to the current forms of reproduction of capitalist social relations (Caffentzis, 2013; Harvey, 2015). From the combination of each of these two movements-the different philosophical stances providing the diverse ontological commitments of each conjuncture analysisdifferent versions of a new communist idea have emerged (Bosteels, 2014).

But why do the "commons" authorize us to speak again of communism as a determinate idea?

In his famous The Great Transformation, Polanyi (2001) distinguished market economy from capitalism proper by first distinguishing between commodities that are the products of human labour and those elements which condition the sphere of production but were not produced by it: land, labour and money (Polanyi, 2001: 71-80). "Land" is to be understood here as the general resources of nature which are in some sense given to us: land, but also water, air, and so on. "Labour" should also be understood not as a specific type of capacity, but as the active forces of men in general-though it remains a heated debate among Marxists if such a thing should be called labour at all (Vicent et al., 1991; Postone, 2009; Larsen, 2014). The inclusion of "money" into this triad might seem at first counter-intuitive, but Polanyi was clearly not suggesting that coins or whatever material support money requires is not man-made, but rather than money depends primarily on a symbolic form of exchange which is not a product of labour, but rather an expression of a more general human resource, which is language. (Polanyi, 2001:75) For Polanyi, the passage from a market economy to a capitalist "system" is defined by the inclusion of these three resources into the commodity form (2001: 45).

This was not a new idea, as Polanyi was the first to recognize, for Marx himself had analysed the "system of bourgeois economy"3 in terms of "the three great classes into which modern bourgeois society is divided": the commodification of labour giving rise to wage-labour, the commodification of land, to landed property and of money, to capital (Marx, 1859: 2). Polanyi was rather interested in the special or paradoxical character shared by these "fictitious commodities": since none of them comes to being through commodity-producing labour, neither land, labour or language is inherently commodified-that is, something readily alienated in the act of exchange-which means that something must be done to these resources so that they might acquiesce to the value-form and thereby be placed in substitutive relations in the market. This is where "fiction" comes in, as the only way to ensure the adequacy of these domains to the rules of commodity exchange is by previously guaranteeing their status as private properties through extrinsic and forceful means: these common resources had to be enclosed-that is, people had to be deprived of the free access to them, either through laws or direct violence-so that, with the mediation of the state, they could begin to be treated as exchangeable goods (Polanyi, 2001: 201-209).

The clarification of this essential interplay between propertyform and value-form, between State and Capital, in the historical constitution of the capitalist mode of production allowed Polanyi to displace the worn-out ideological polarization between free capitalist markets and state regulation (2001: 231-244). But even if his own immediate objective was to intervene in this particular debate, the theory of "fictitious commodities" has broader consequences, which directly relate to the struggle over a new determination of the communist idea today.

As philosopher Slavoj Žižek writes:

It is not enough simply to remain faithful to the communist Idea; one has to locate within historical reality antagonisms which give this Idea a practical urgency. The only true question today is: do we endorse the predominant naturalization of capitalism, or does today's global capitalism contain antagonisms which are sufficiently strong to prevent its indefinite reproduction? There are such four antagonisms: the looming threat of an ecological catastrophe; the inappropriateness of the notion of private property in relation to so called "intellectual property"; the socio-ethical implication of new techno-scientific developments (especially in biogenetics); and, last but not least, the creation of new forms of apartheid, new Walls and slums. There is a qualitative difference between this last featurethe gap that separates the Excluded from the Includedand the other three, which designate different aspects of what Hardt and Negri call "the commons", the shared substance of our social being. (...) What the struggles in all these domains share is an awareness of the potential for destruction, up to and including the self-annihilation of humanity itself, should the capitalist logic of enclosing the commons be allowed free run. (Žižek, 2009: 90-91)

In a way that resonates with Marx's and Polanyi's categorizations, Žižek distinguishes between the commons of culture-"the immediate socialized forms of "cognitive" capital, primarily language"-the commons of external nature-our natural environment-and the commons of internal nature-"the biogenetic inheritance of humanity" (2009: 91). To these he adds, highlighting its centrality and qualitative distinction, the enclosure of people, through new forms of apartheid.

Our ultimate objective in this essay is to reconstruct the theory of the commons from the standpoint of this fourth antagonism, a form of enclosure that should not be solely defined by the walls and spatial constraints it imposes, but also, and even more profoundly, by the way this process leads to an expropriation of our capacity for self-estrangement.

However, for such broader reconstruction to be possible, we must begin by analysing the historical transformations which affected one of Polanyi's three special commodities: the shift in the role of labour in the productive process and what has been called the "crisis of value". 4

\section{The crisis of value}

In Marx's formula for capital (Marx, 1867: 104-110), presented early on in the first volume of Capital, ${ }^{5}$ we have a cycle which begins with money (M), then invested into two sorts of commodities: means of production (MP), which include land, raw or pre-processed materials, energy resources, machinery, and so on, and labour power (LP). The labourer works on the means of production, producing a certain amount of commodities (C). Leaving the productive sphere and entering the domain of circulation, these commodities are then to be sold-this is what Marx calls the "salto mortale" (Marx, 1867: 72) of the commodity, its exchange-for more money ( $\left.\mathrm{M}^{\prime}\right)$. The formula is reproduced in Fig. 2.

The first thing to note is that there is a reason why LP is set aside as a separate variable. As we have seen, labour is a special 


$$
\mathrm{M} \rightarrow \mathrm{MP}+\mathrm{LP} \rightarrow \mathrm{C} \ldots \mathrm{C} \rightarrow \mathrm{M}^{\prime}
$$

Figure 2 | Marx's expanded formula of capital. This formula articulates the passage of $M$ (money) from the circulation sphere to the sphere of production as it buys MP (means of production) and LP (labour power) to produce $C$ (commodity). This commodity must then leave the production sphere and be sold in the market for $\mathrm{M}^{\prime}$ (more money).

sort of commodity. For Marx, commodities are valued by the socially necessary labour time to produce them (Marx, 1867: 3033)-which means that, if on average one takes two hours of work to produce a coffee mug, the extra six hours it took me to make a similar one, due to my personal artisanship or lack thereof, will simply not be "absorbed" by the commodity I produced, it will be worth the same two hours of labour as every other coffee mug of that kind. In short, the value-form does not only make different commodities substitutable among each other-a certain proportion of any item A being equivalent to another proportion of item $\mathrm{B}$-but, more radically, makes it so that a commodity is nothing but this potential of substitution: it is exchangeable for other commodities and for another of its own kind (1867: 27).

This is important because when we extend this same logic to labour, something like a "glitch" appears, an effect of its "fictitious" status as a commodity. If the exchange value of commodities is set in accordance to their substitutability, in relation to other commodities and to other copies of itself, while their use values concerns their consumption, then the exchange value of the labour-commodity should also be set by the cost of its reproduction-the cost of having another labourer, the same person or not, doing that same work again-while the use value of labour is given by its consumption (1867: 119). Now: when labour is consumed during the production process, it can produce an amount of value which is not directly constrained by its exchange-value-that is: it can produce more value than it is worth (1867: 131-140).

Consider now-while excusing the utter simplification of the example-that a capitalist hires a worker and pays her $5 \$ /$ hour in a $8 \mathrm{~h}$ workday to produce coffee mugs. Using the current MP, a worker is capable of producing four mugs per hour, each of them later sold for $5 \$$. That totals $160 \$$, an amount which has to cover not only for her $40 \$$ daily wage, but also partake in the other costs of production, rent, bills, taxes, and so on, say, another $80 \$$. Now where did the difference-these added $40 \$$-emerge from? If we consider the process through which the labour-commodity was consumed, we can see the virtual emergence of this surplus: if each coffee mug costs $5 \$$, and each worker produces four of them per hour, after $4 \mathrm{~h}$ of work each labourer produced $80 \$$ worth of mugs, that is, each worker produced the equivalent to the value of their own labour. The remaining $4 \mathrm{~h}$ of work, in which an additional $80 \$$ per worker is produced, created additional value that belongs to the capitalist, who needs to pay for the MP and is entitled to the remaining surplus (see Fig. 3).

Marx called absolute surplus value (1867: 126) the surplus extracted from the differential between the time needed for the worker to produce the equivalent to his labour's worth-which is defined not by the capitalist, but, as every other commodity, by the exchange value of labour force, its cost of reproduction-and the remaining productive time, in which the worker continued to produce value. The arrow in the above representation stands for the way in which this surplus is extracted: the more hours of labour, the more surplus is produced.

But Marx also conceptualized what he called relative surplus value (1867: 219), the surplus which is not extracted by the expansion of the work day, or the expansion of the workforce, but rather by the increase in productivity. So, let us now consider that this same capitalist has invested in new machinery for his mug

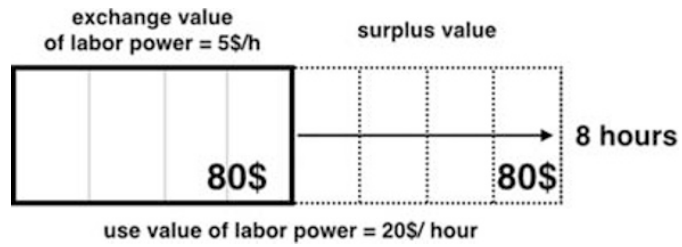

Figure 3 | Example of absolute surplus-value extraction. This figure shows how absolute surplus value is extracted by an increase in the number of hours that the worker labours besides those needed to pay the cost of reproduction of his own labour power.

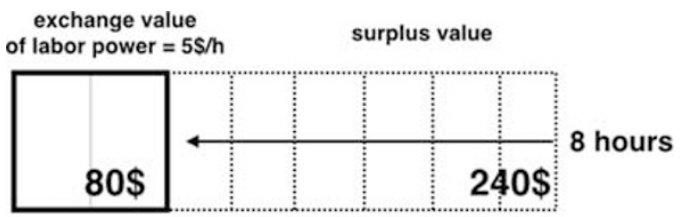

use value of labor power $=40 \$ /$ hour

Figure 4 | Example of relative surplus-value extraction. This figure shows how relative surplus-value is extracted by an increase in productivity, that is, by increasing the amount of value produced in the same number of hours, so that the time needed for the worker to produce as much as his own reproduction costs are worth is shortened.

factory. With this new machinery, each worker is capable of producing eight mugs per hour, instead of the previous four. So, in the same $8 \mathrm{~h}$, instead of producing $160 \$$, each worker will produce $320 \$$ worth of coffee mugs. Furthermore, rather than taking four hours to produce the equivalent to her wage, now the worker takes only $2 \mathrm{~h}$, as depicted in Fig. 4 .

As the arrow indicates, surplus is not extracted here by a quantitative increase in work hours or number of workers employed, but rather by a qualitative increase in what an hour of work can produce. Depending on the costs of these new MP, the capitalist could even decrease the number of hours he buys for 80 $\$$, paying his workers $80 \$$ for $6 \mathrm{~h}$, and still extract more surplus from this more "Swedish" workdays than from the $8 \mathrm{~h}$ under the previous production rate.

So while the extraction of absolute surplus value depends on a quantitative relation between capitalist and workers, leading capitalists to push for longer workdays, worst conditions of work, and the employment of many wage workers, relative surplus value depends on a qualitative relation, effected not so much through direct confrontation between the capitalist and the worker, but through the indirect means of technological advance, which does not require the same alliance between expansion of workforce and extraction of surplus (1867: 367).

We are now in condition to understand what the "crisis of value" means. Until now, we have only analysed the "virtual" aspect of surplus extraction, conditioned by the organization of the productive sphere, but which is not realized as profit if the batch of coffee mugs is not successfully sold in the marketplace afterwards-that is, if the "leap" of the commodity is not successfully accomplished. The problem becomes clear when we are reminded that commodities are mostly bought back by wage workers themselves (as shown in Fig. 5). Just like every commodity is divided between its exchange and its use values, so is the worker divided between herself as a producer-a seller of a certain commodity-and a consumer-a buyer of the necessarily resources to reproduce her labour force and return to work the next day (Engels, 1888: 153).

There seems to be a "balance" in this cycle when orienting principle of the productive sphere is the extraction of absolute 


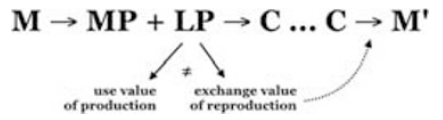

Figure 5 | The two sides of labour power. This figure expands the LP element of Marx's formula for capital to show the differential between the use value and the exchange value of the labour-commodity.

surplus value, since the more the capitalist employs workers, the more he extracts surplus value, and the more there are wage workers, the more there are means for people to buy back what has been produced (1888: 150). This is the sort of intuition at stake, for example, in Henry Ford's vision of workers who are paid enough to buy the cars that they were building in his factory. There are, evidently, serious caveats to the supposed harmony of such cycle, but what matters to us here is, first of all, the common horizon of full employment shared by capitalists and workers alike (Kurz, 1994; Buck-Morss, 2002; Weeks, 2011): even though a vicious struggle exists here, with workers seeking to reduce the work journey, get better conditions of labour and participate more and more in the coordination and destiny of their own efforts, while the capitalist exacts force in the other direction, both conflicting parties share the premise that the productive sphere is all the better equipped the more workers it absorbs, for this implies a larger capacity to consume what has been produced by society. The problem arises when the "social synthesis" of capitalist production is not centered around absolute, but relative surplus value extraction-which, unlike its uglier and brute counterpart, does not preserve the horizon of total workerconsumer absorption. As we have seen, increases in productivity are not proportional to increases in employment-in fact, as machinery becomes more automated, the less workers are needed to produce increasingly vaster amount of commodities. But if less workers are employed, there are less wealth in their hands to buy back the overproduction of goods, thus compromising the transformation of the virtual increase in surplus extraction into actual profit for the capitalist (Engels, 1888: 171-182).

If the extraction of absolute surplus creates a conflict between the buyers and the sellers of the labour-commodity-capitalists and workers-relative surplus value lays bare the schism between production and consumption as such. And while, in the first case, the tensioned mediation of the struggle appears, for example, in the sort of labour legislation that is approved, benefiting one of the two conflicting social classes, in the second case, the fracture between the worker-as-producer and the worker-as-consumer is to be "mended" through a series of different mechanisms-like social security in a Welfare State-the most important of which is the facilitation and expansion of credit (Graeber, 2011; Lazzarato, 2015).

It is against the background of this structural crisis, leading to important transformations in the logic of capitalist valorization, that the impasse of the commons gains its proper contemporary import.

\section{The commons as common ground}

Perhaps the most emblematic version of the "communism of the commons" today is the political project of Antonio Negri and Michael Hardt, developed in the course of three books-Empire (Hardt and Negri, 2000), Multitude (2004) and Commonwealth (2009). As we have previously mentioned, each particular political perspective on the question of the commons is mediated by a specific philosophical background, and this is also the case for Hardt and Negri's program. Departing from a Spinozist perspective-that is, locating the common there where creative, infinite and affirmative forces are at play (Negri, 2013: 35-54)these communist thinkers read the crisis of value as a process which has led capitalism to increasingly depend both on the privatization of natural and cultural resources and on the direct and immediate social cooperation between people:

Capitalist development inevitably results in the increasingly central role of cooperation and the common, which in turn provides the tools for overthrowing the capitalist mode of production and constitutes the bases for an alternative society and more of production, a communism of the common. (Hardt in Žižek and Douzinas, 2010: 240)

As we have argued, this diagnosis is based on a particular philosophical vision of what is truly "real" behind the "fiction" of Polanyi's "fictitious commodities". But this Spinozist understanding of the commons is combined an interesting analysis of the contemporary structure of the capitalist mode of production. So let us return once more to Marx's formula of capital and analyse how it is that cooperation and the commons might appear within this structure.

For this, we must pay special attention to the composition of what was previously condensed simply as "means of production" (MP) - as expanded in Fig. 6.

As we have seen, the qualitative change that allows the capitalist to extract relative surplus value is a change in the amount and quality of commodities that can be produced while labour time remains constant. The worker might continue to do the exact same thing, overseeing a certain machine, but if that machine has been upgraded in some way, this might lead to a higher rate of production (Marx, 1867: 367). What this shows is that, the more relative surplus value becomes the orienting form of surplus extraction, the more important the technical knowledge that goes into improving a machine becomes (Kurz, 2014).

When Marx analysed this new role of science and knowledge in the extraction of surplus value in the Grundrisse, ${ }^{6}$ he was taken by the strange inversion this seems to bring about (Marx, 1861: 377). Marx categorizes machines as "constant capital"-dead labour incapable of creating value if there is no living labour employed there-and workers as "variable capital", since, from the standpoint of absolute surplus value, the variation in the extracted surplus is determined by the variation in the amount of living labour employed in production (Marx, 1867: 142). But when the dead labour that is crystallized in the use value of the machinery is conformed by intellectual labour in such a way as to increase the productivity of a certain product by tenfold, while the living labour employed in this new scenario remains practically the same, these two poles seem to invert: it is workers who appear as constant capital, deadened and repetitive, while the variations in the science that went into making that machine are affecting the value output of production. The precision here is crucial: the material reality of the machinery remains what it always wasdead labour that only depreciates as the machine is consumed in the production process, and which cannot produce more value that it is itself worth-it is the knowledge that went into making the machine which transforms the capacity of the machine to extract more value out of the same living labour employed in this process (Marx, 1861: 377-379).

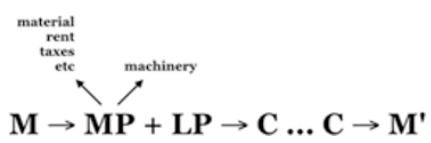

Figure 6 | The components of the means of production. This figure expands the MP element of Marx's formula for capital to show the qualitative difference between the machinery and other means of production. 
So, on the one hand, the principle that only labour can create value remains preserved, since, in some sense, even if radically decomposed between the intellectual effort of creating new technological means and the actual expenditure of physical energy that went into making the new machines, there is still necessary concrete labour behind the dead machinery. It is important to note that some authors treat the two aspects of this disjunction as separate forms of labour, since each aspect is increasingly embodied by different people, believing that we would need a new theory capable of accounting for pure "immaterial labour" and its capacity to create value and arguing for a complete reconsideration of the Marxist theory of labour (Toscano, 2007). Although we cannot go into this debate here, it is sufficient to point out that this is not a necessary conclusion, for we can just consider, instead, that "labour" remains as always a composite of intellectual and manual activities, and that without the concrete construction of the new advanced machineryhowever, minuscule the contribution of this construction might be to the value of the new production output-the incredible technological discoveries would simply not have any effects. In short, rather than a new theory of labour, we could just distinguish as in Fig. 7, between the structure of labour and the structure of the labourer, the necessary composite of intellectual and manual activities from the spontaneous equivalence with the head and hand of one and the same body.

But this does not mean that this transformation does not bring about important changes to capitalist social relations. The first of them concerns, precisely, the inadequacy of knowledge to the commodity-form.

As we have seen, Polanyi named resources like land, labour and language "fictitious commodities" because these are elements which are not alienable in the sense that commodities must be if they are to be exchanged-something must be done to them so that they are conformed to the status of private properties. As Marx writes:

Commodities are things, and, therefore, without power of resistance against man. If they are wanting in docility he can use force; in other words, he can take possession of them. In order that these objects may enter into relation with each other as commodities, their guardians must place themselves in relation to one another, as persons whose will resides in those objects, and must behave in such a way that each does not appropriate the commodity of the other, and part with his own, except by means of an act done by mutual consent. They must, therefore, mutually recognize in each other the rights of private proprietors. (Marx, 1867: 60)

It is crucial to realize that the logic of value is not the same as the logic of property (Karatani, 2014: 1-27). Commodities relate to one another through exchange, and even the removal of a given commodity from circulation, for purposes of production or consumption, does not remove it from the network of value relations within which it is inscribed. Relations of private

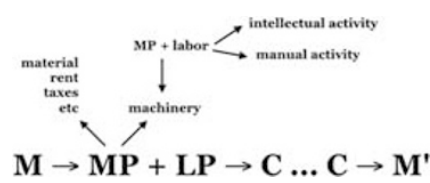

Figure 7 | The role of knowledge in productivity increase. Here we distinguish the factors responsible for the increase in productivity through technological improvements, highlighting the importance of intellectual activity in this process. property, on the other hand, are not defined by the things themselves, but by the relation between their proprietors: I am the proprietor of a given thing if others are not, that is, if they are deprived of it. In other words, the value of a commodity depends on its use value for others, its "social use value" (Marx, 1867: 30) -even if its use turns out to be further exchange-while the rights over a property are defined by the privation of its access for others. In short, if have a commodity that only I can use, then even if it is my private property, it is not a commodity, while if I have a property that others want and already have access to its fruition, even if it has use value for others, it is not a private property. As Marx points out, in order for the logic of commodity exchange to be put into place, the relations of private property must structure the relation between the owners of commodities, which in turn are themselves conditioned by the relations between the commodities themselves-but it is important to note that this co-dependence does not authorize us to reduce the determinations of the logic of value to those of property relations or vice-versa (Nascimento, 2012: 21-23).

The commons of land, labour and language all pose problems to the logic of value. When something is produced in the capitalist mode of production-that is, through the purchase of $\mathrm{MP}$ and $\mathrm{LP}$ - the capitalist's investment $(\mathrm{M} \rightarrow \mathrm{MP}+\mathrm{LP})$ already pre-determines the ownership relations of the production output $(\mathrm{MP}+\mathrm{LP} \rightarrow \mathrm{C})$ (Ellerman, 1997). Both the MP and the LP were purchased as private property, alienated from their previous owners, so the question of who owns the production output is not really an issue: they belong to whoever owned the commodities that went into making it. But what about the commons? Since they are not produced under the rules of private ownership, which would guarantee their later exchangeability, they must first be segregated, their use by others impeded, so that a lake, someone's time or an idea can be considered a property, and, therefore, something which can be alienated, passed on and possessed by someone else, in the market.

In his discussion of "primitive accumulation" in the first volume of Capital, Marx uses the example of England, between the fifteenth and the eighteenth centuries, to show how it is that the enclosure of the commons produces the three main classes of capitalist societies (Marx, 1867: 506-540) The enclosure of communal properties, first through directly violent means but then later through new legislation, turns them into private property, depriving a huge number of peasants from their means of subsistence. But the dispossessed are not only deprived of a place to live, they are also deprived of means to employ their labour time as they see fit-that is, they are thereby required to sell their labour to others, for they cannot directly benefit from it. Alienated from their own use value as labourers, since their labour is only private property insofar as it is sold for someone who owns means to employ them-the class of those who own MPthe dispossessed become owners of their own labour as commodities (Van der Linden, 2010).

If we now take a look at the status of knowledge, we can see that it presets a similar challenge to the logic of value. Knowledge is not immediately conformed to the property form: even though knowledge is, in some sense, created by us, when we transmit knowledge to others, we do not stop knowing it ourselves. And so, as scientific developments become increasingly more important for capitalists to continue to extract relative surplus value, so does the search for ways to conform knowledge into the logic of enclosures and privatizations, specially through the notion of "intellectual property" (Teixeira and Rotta, 2012).

For Hardt and Negri, this shift in the composition of living labour does not only transform the fronts of struggle-placing international mechanisms for guaranteeing the enclosure of the "general intellect" at the centre of the battle, which they call the 
"Empire" (Hardt and Negri, 2000: 160-204)—it also transforms the quality of the social agents capable of fighting our current predicament. This concerns another aspect of intellectual activity which is at odds with the reinforcing logics of value and property.

When a worker sells his labour to a capitalist who owns a coffee mug factory, she enters a process in which her relation with other workers-with those who could have taken her job, those who work on products that she will later consume with her wage, and so on-is mediated by commodity exchange. Nothing in her social place as a worker is immediately visible as social: if we ask what she is doing there, producing coffee mugs, her answer will be that she needs a job that pays her at least $5 \$$ an hour. It is only if we ask her labour itself, if we listen to it in the "language of commodities" (Marx, 1867: 36) that the determinations of her workday become clear: why it is that her hour of work is worth 5 $\$$, why each coffee mug is being sold by a certain amount-and even why it is that the capitalist is making mugs instead of something else. Commodity fetishism-the way "relations between people appear as relations between things" (1867: 48) -is not an illusion that covers up and hides the truth of the capitalist productive sphere: it is only when looking at people as if looking at commodities that the real determinations of the law of value become legible (Žižek, 1989; Karatani, 2003). In an economic system primarily based on the enclosure of labour time, social relations are mediated by commodity and property relations, and each worker immediately confronts her fellow workers as separate and unrelated individuals.

The intellectual activities that go into technological innovation, however, seem to change this: insofar as they resist the propertyform, the social cooperation between intellectual labourers is immediately visible, they are traceable by the path left by the transmission of knowledge, and the social dimension of this activity is embedded in the very potency of knowledge to be shared with everybody. In this sense, the more that capitalism relies on relative surplus value extraction, the more it will rely on knowledge, which in turn would lead to "the increasingly central role of cooperation and the common", as Hardt concludes. These communist thinkers also suggest that, the more capitalism depends on intellectual property, the more it also undermines commodity fetishism, substituting it for a transparent social network in which Capital acts no longer through ideology, but blunt visible power (Hardt and Negri, 2000: 240).

Just as the centrality of the commons in contemporary capitalism would require us to name the "Empire"-the global partnership of State and Capital, of the privatization and commodification of the commons-as our main enemy, so does the new form of immediate social cooperation between cultural labourers require us to rethink the social actors capable of countering it. Following Spinoza, Hardt and Negri call this new immediate form of collective creation the "Multitude" (Hardt and Negri, 2004: 211): an immediate, affirmative and creative force that produces social life in a way that defies both private and public forms of property, and, therefore, potentially resists the enclosures, which alone can save capitalism from its structural crisis.

There is, however, a conceptual leap between, on the one hand, the critical analysis of the crisis of value, the role of enclosures and the renewed alliance between State and Capital, and, on the other, the conclusion that the commons, in their immediate form, can serve as a springboard to a positive new vision of the communist idea-a leap that depends on the particular philosophical view, which underpins the theory of the commons at stake here.

\section{The ideology of the common}

We briefly mentioned in our introduction that, in the Communist Manifesto, Marx and Engels denounce that the principles which the utopian socialists evoke to counter the recently established capitalist society belong to the feudal world that was still in the process of disappearing. The trust in the capacity of immediate communal life to serve as an antidote to class antagonisms, old and new, relied on a hybrid position - both socially aware of the new critical situation of the forming working class and ideologically tied to a pre-modern view of social relations-a view that had no basis in the developing material tendencies of capitalism itself:

Such fantastic pictures of future society, painted at a time when the proletariat is still in a very undeveloped state and has but a fantastic conception of its own position, correspond with the first instinctive yearnings of that class for a general reconstruction of society. But these Socialist and Communist publications contain also a critical element. They attack every principle of existing society. Hence, they are full of the most valuable materials for the enlightenment of the working class. The practical measures proposed in them (...) point solely to the disappearance of class antagonisms which were, at that time, only just cropping up, and which, in these publications, are recognized in their earliest indistinct and undefined forms only. These proposals, therefore, are of a purely Utopian character. The significance of Critical-Utopian Socialism and Communism bears an inverse relation to historical development. In proportion as the modern class struggle develops and takes definite shape, this fantastic standing apart from the contest, these fantastic attacks on it, lose all practical value and all theoretical justification. (Marx and Engels, 1848: 32)

There seems to be an uncanny element of repetition here, as the idea of communism espoused by utopian socialists took the very thing that had been lost through that initial wave of primitive accumulation-communal properties-as the standpoint of their positive view of an alternative society-communal collective life-while the new idea of communism espoused by the defenders of the multitude take the very thing that is being currently privatized-cultural creation of knowledge-as the basis for their strategic view of a "communism of the commons". Just as it was ultimately the process of dispossession of land and labour which gave the defenders of the commune the idea that sharingthe lost-land and labour could counteract the capitalist tendency towards social mediation through commodity exchange, the view that culture can produce an immediate form of social link, binding citizens together as producers and consumers of collective forms of life (Hardt and Negri, 2004: 103-115), can only emerge as a possible social common ground after the commons of culture have been privatized.

This leads us in fact to a crucial realization, which must be considered by any Marxist theorization of the commons looking to renew the communist idea. As we have just seen, the enclosure of the commons opens the space to critical positions which, aware of the alliance between State and Capital in the process of primitive accumulation, evoke the communitarian spirit as a revolutionary resource. For both the utopian socialists and the new cultural communists, the immediate social homogeneity of those who share the same symbolic space, of those who have lost the same thing through the privatization of their territory or their culture, appears as an ally against the global force of State-Capital. What we should realize, however, is that this shared symbolic heritage is in fact constituted by its very loss: that is how the "imagined communities" are born, by acquiring a common past, sharing a common burden, being inscribed in the same "timeline" through the admission of a certain debt to be repaid in the 
infinitely distant future (Anderson, 2006: 9-48). That is ultimately why the births of the modern State and of capitalism were accompanied, and conditioned, by the emergence of the modern Nation.

In his masterful The Structure of World History, Kojin Karatani summarizes this triple interdependence, which prevents communitarianism from pointing a way out of the State-Capital system, in the following way:

Today's advanced capitalist nations are characterized by a triplex system, the Capital- Nation- State trinity. In its structure, there is first of all a capitalist market economy. If left to its own devices, however, this will inevitably result in economic disparities and class conflict. To counter this, the nation, which is characterized by an intention towards communality and equality, seeks to resolve the various contradictions brought about by the capitalist economy. The state then fulfills this task through such measures as taxation and redistribution or regulations. Capital, nation, and state all differ from one another, with each being grounded in its own distinct set of principles, but here they are joined together in a mutually supplementary manner. They are linked in the manner of a Borromean knot, in which the whole system will fail if one of the three is missing. (Karatani, 2014: 1)

What this entails is that we should think of the enclosure of the commons not only as being operated by the property and the commodity forms, but also by the community-form (Linera, 2011), which forms pockets of social cohesion around this loss.

Considering this "triplex system", depicted in Fig. 8, we are better equipped to consider another aspect of the critique of the utopian socialists that is also valid for the cultural communism of Hardt and Negri. The idea that we might have an unmediated, immediate access to the commons implies that any strategic vision or any political experiment which orients itself by it will already be acting on accordance to common interest. This premise threatens to turn the idea of communism into an ideology of the commons, which improperly generalizes the particular world view of a given sector of society:

The undeveloped state of the class struggle, as well as their own surroundings, causes Socialists of this kind to consider themselves far superior to all class antagonisms. They want to improve the condition of every member of society, even that of the most favoured. Hence, they habitually appeal to society at large, without the distinction of class; nay, by preference, to the ruling class. For how can people, when once they understand their system, fail to see in it the best possible plan of the best possible state of society? (...) although the originators of these systems were, in many respects, revolutionary, their disciples have, in every case,

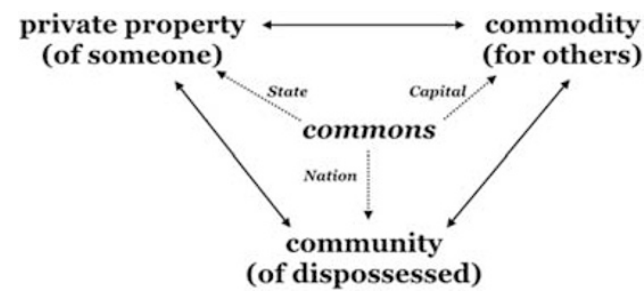

Figure 8 | Kojin Karatani's triplex system. Here, we depict Kojin Karatani's schematization, which suggests the enclosure of the commons gives rise to a trinitarian organization where private property, commodity exchange and communities reinforce each other. formed mere reactionary sects. They hold fast by the original views of their masters, in opposition to the progressive historical development of the proletariat. They, therefore, endeavor, and that consistently, to deaden the class struggle and to reconcile the class antagonisms. (...) By degrees, they sink into the category of the reactionary (or) conservative Socialists depicted above, differing from these only by more systematic pedantry, and by their fanatical and superstitious belief in the miraculous effects of their social science. (Marx and Engels, 1848: 33)

Slavoj Žižek's insistence on a qualitative distinction between the enclosure of the commons of nature and culture, on the one hand, and the new forms of apartheid, on the other, allows us to recuperate this argument from a structural point of view:

The ongoing enclosure of the commons concerns the relations of people to the objective conditions of their lifeprocess, as well as relations between people: the commons are privatized at the expense of the proletarianized majority. There is nevertheless a gap between these two aspects-the commons can also be restored to collective humanity without communism, in an authoritarian-communitarian regime; the de-substantialized 'rootless' subject, deprived of its substantial content, can also be counteracted in the direction of communitarianism, by finding its proper place in a new substantial community. (...) Socialism wants to solve the first three antagonisms without the fourth one, without the singular universality of the proletariat. (Žižek in Žižek and Douzinas, 2010: 214)

Both Karatani and Žižek focus their critiques of the communitarian struggle against the enclosure of the commons on the structurally reactionary effects of trusting the logic of nations and communities against the impersonal link of State and Capital, for these are essentially oppositional logics, always in need of a concrete enemy or scapegoat (Dupuy, 2013: 116). But there is a philosophical underpinning to this strategic trust, a commitment which makes it hard to separate the commons from the social homogeneity proper of communities, and, therefore, to distinguish between the ideology of the class of cultural workers, who experiment a certain form of immediate social cooperation among themselves, as Hardt and Negri rightfully realize, and the theoretical apprehension of the true reach of this cooperative and common ground. This is, ultimately, the limit of both religious and secular ontologies committed to the idea that there must be, necessarily, something positively common to all human beings (Žižek and Milbank, 2011; Zižek, 2012): the utopian socialists of the past leaned on a Christian understanding of human nature, just as the new cultural communists trust a Spinozist view of being which, giving essential precedence to positivity over negativity, gives equal precedence to a basic and unalienable social homogeneity between people over any form of social disaggregation. In the case of Hardt and Negri, who are evidently not so brute as to defend that "everyone is deep down the same", this commitment emerges rather as a trust that the absolute heterogeneity between people emerges as a nonconflictive, creative and affirmative force (Žižek and Douzinas, 2010: 156-159). What becomes inconceivable from this perspective is the possibility that the "multitude" might be composed of social fragments, which have "sharp edges": the closer we are brought together, through the construction or the suspension of walls, the greater the antagonism and the "cultural wars" among us. To return to an old and forgotten jargon: what becomes unthinkable is the possibility that the antagonisms "within the people" might become more conflictive than the antagonisms 
between the people and the "enemies of the people" (Žižek, 2012: 963).

This has, in fact, turned out to be the case today. The constant threat of cultural privatization has indeed awaken the class of intellectual workers to the pressing dangers of capitalism, highlighting that they are not innocent bystanders of class conflicts at the same time that it has rendered legible the singular situation of "cognitive" work with regards to the logic of valorization and private property. This, however, has also led to the mistaken belief that this particular sector of the working class is also its new essential element and that its interests, principles and values represent the working class as a whole, a mistake which is encouraged by the ideology which generalizes the presupposition that the fight for the commons always brings about a community. And just as in the case of the utopias of XVIIIth century socialists, the contemporary communists of the cultural commons lose themselves in "their fanatical and superstitious belief in the miraculous effects of their social science", ultimately losing track of the effective material constraints being produced by capitalism and, at times, even helping to increase the already tensioned and conflictive relation between cultural workers and other fragments of the working class.

\section{The estrangement of the commons}

Distinguishing the commons from the community-form poses, however, serious theoretical difficulties. For example, when Žižek declares that we must not only recognize the qualitative difference between the enclosures of culture and nature and the enclosure of people, but also conceive struggle against the former from the standpoint of the latter, how is this strategically different from espousing a political program based on social inclusion? Furthermore, if we suspend our commitment to the presupposition that the access to the commons is essentially communitarian, that is, if we are faced with the possibility that those who are segregated from the social space do not necessarily share among themselves or with others any effective common ground, how could the standpoint of the excluded be affirmatively conceived?

To address these issues, let us return once more to the "crisis of value". Less seduced by the ideological effects brought about by the new role of the cultural commons in contemporary capitalism, we are now in position to trace its consequences for the other fragments of the working class.

In our initial analysis of the structural transformations brought about by the shift in hegemonic form of surplus extraction, we noticed that a fundamental difference between a capitalist mode of production centered on the extraction of absolute surplus directly from the worker's labour time, and one centered on the relative extraction, through increases in productivity, concerns the latter's breaking of a certain silent "pact" between workers and capitalists: the horizon of full employment, that is, the common view that a "society of work" is a desirable or attainable future:

The normative expectation of waged work as an individual responsibility has more to do with the socially mediating role of work than its strictly productive function. Work is the primary means by which individuals are integrated not only into the economic system, but also into social, political and familial modes of cooperation. That individuals should work is fundamental to the basic social contract; indeed, working is part of what is supposed to transform subjects into the independent individuals of the liberal imaginary, and for that reason, is treated as a basic obligation of citizenship (The fact that the economy's health is dependent on a permanent margin of unemployment is only one of the more notorious problems with this convention). Dreams of individual accomplishment and desires to contribute to the common good become firmly attached to waged work, where they can be hijacked to rather different ends: to produce neither individual riches nor social wealth, but privately appropriated surplus value. The category of the work society is meant to signify not only the centrality of work, but also its broad field of social relevance (Weeks, 2011: 8)

Work could be seen as a principle of social synthesis insofar as the underlying logic behind absolute surplus extraction guarantees a certain cycle, binding the increase in labour time employed in the production process with the increase in wage labourers capable of buying back the commodities being produced. But one of the principle effects of the increasing centrality of relative surplus extraction, itself caused by the structural exhaustion of the previous moment, ${ }^{7}$ is that this guarantee becomes unsustainable. Not as a reality-which it never was-but as a horizon which promoted social homogeneity:

The elimination on a massive scale of living productive labour as a source of the creation of value can no longer be recuperated by newly massproduced cheap products, since this process of mass production is no longer mediated by a process of reintegrating a labour population that has been made superfluous elsewhere. This brings about a historically irreversible overturning of the relationship between the elimination of living productive labour through scientification on the one hand, and the absorption of living productive labour through processes of capitalization or through the creation of new branches of production on the other: from now on, it is inexorable that more labour is eliminated than can be absorbed. All technological innovations that are to be expected will also tend only in the direction of the further elimination of living labour, all new branches of production will from the outset come to life with less and less direct human productive labour.

(Kurz, 2014: 24)

The first volume of Capital offers us two distinct entry points: the first, a logical analysis of the secret of the commodity-form, introduces us to the laws of commodity exchange-laws written in "social hieroglyphs" (Marx, 1867: 49)—while the second, a historical analysis of the secret of primitive accumulation, introduces us to the constitution of the labour-commodity, a history written in "letters of blood and fire" (1867: 508). However, as Fredric Jameson suggests, when these perspectives are forced together, Capital reveals itself to be neither a book about the logical exploitation of the use-value of concrete labour, nor about the historical constitution of abstract labour, but rather a book about unemployment: ${ }^{8}$

Unemployment has often been grasped as the ideological other face of a whole political program based on the call for "full employment"; and while I think this slogan might be good and invigorating for us in the current conjunctureparticularly since it is unrealizable within the system and, therefore, calculated to dramatize everything nonfunctional about its structure-I believe that it is not necessary to invoke this political and ideological strategy when insisting on the fundamental structural centrality of unemployment in the text of Capital itself. Marx does not there call for the correction of this terrible situation by a policy of full employment; rather, he shows that unemployment is structurally inseparable from the dynamic of accumulation and expansion which constitutes the very 
nature of capitalism as such. (...) It suggests that those massive populations around the world who have, as it were, "dropped out of history," who have been deliberately excluded from the modernizing projects of First World capitalism and written off as hopeless or terminal cases, the subjects of so-called "failed states" (a new and self-serving pseudo-concept) or of ecological disaster or of oldfashioned survivals of allegedly immemorial, archaic "ethnic hatreds," the victims of famine whether manmade or natural-all these populations at best confined in camps of various kinds, and ministered to by various NGOs and other sources of international philanthropyour reading suggests that these populations, surely the vessels of a new kind of global and historical misery, will look rather different when considered in terms of the category of unemployment. (Jameson, 2011: 148-149)

It is, in fact, when we conceive of unemployment as an active element of the capitalist dynamic of accumulation that we are able to truly conceptualize the enclosure of labour as a commodity. If we adopt the "logical" entry point into Capital, looking at the labour-commodity as we would do at any other product of the capitalist mode of production, it is only by considering the social relation between a given worker and the rest of the unemployed workforce that we can truly grasp the determinants for the exchange-value of this commodity (Marx, 1867: 507). When Marx writes that the value of a commodity is given by the "socially necessary labour time" that goes into its reproduction, we must also extend the reach of this definition to include the value of the labour-commodity, which is constituted as such in relation to the LP potentially at disposal in the market. The unemployment of others is, therefore, a determinant for the conditions of employment of some. But unemployment also helps us to clarify aspects of the historical approach to capitalism, the one that begins with primitive accumulation. In fact, it helps us to see that, historically, unemployment precedes employment: workers were first "freed" from their means of subsistence, deprived of ways to make direct use of their own active forces, and only through this privation is that LP emerges as a "homogeneous substance", which can be employed as expenditure of time in different productive contexts. In other words, unemployment functions as a form of enclosure, a form of privation, which has a formal role in "molding" one's heterogenous capacities into the negative and homogenous power that is labour time as a private property. Finally, when considered together, we see that one's own unemployment is a condition for labour to be abstracted into a commodity that has use value for others, while the other's unemployment is a condition for this commodity to have exchange value, and therefore revert into wages for oneself.

That is why, when summarizing the "absolute general law of capitalist accumulation", Marx does not constrain his analysis to the extraction of surplus from workers employed by capitalists, but rather points to the distinction between the "reserve army" and the "active labour army":

The greater the social wealth, the functioning capital, the extent and energy of its growth, and, therefore, also the absolute mass of the proletariat and the productiveness of its labour, the greater is the industrial reserve army. The same causes which develop the expansive power of capital, develop also the labour power at its disposal. The relative mass of the industrial reserve army increases, therefore, with the potential energy of wealth. But the greater this reserve army in proportion to the active labour army, the greater is the mass of a consolidated surplus population, whose misery is in inverse ratio to its torment of labour.
The more extensive, finally, the lazarus layers of the working class, and the industrial reserve army, the greater is official pauperism. This is the absolute general law of capitalist accumulation. Like all other laws it is modified in its working by many circumstances, the analysis of which does not concern us here. (Marx, 1867: 450)

At first, the distinction between the "surplus population" and the active working class seems secondary: sociologically verifiable, but theoretically unimportant, given that, to extract absolute surplus value, capitalists must employ as many workers as possible, benefiting from unemployment rates only insofar as they drive the price of labour down. But, with the so called "crisis of value", the unemployed can no longer be conceived as the "potentially employable" or the "not yet employed"-instead, under the aegis of relative surplus extraction, it is the active worker who must begin to consider his condition as worker as an accidental or momentary expression of his more essential role as an increasingly superfluous labourers (Kurz, 2014).

Just as the crisis of value has prompted a massive return to the direct spoliation of common resources, and an expansion of its reach to include the privatization of cultural productions, so it has also brought forth a forgotten truth about the labour-commodity in capitalism: that its very commodification is shaped by the phantasm of those who cannot work. However, while the huge masses of unemployed in early capitalist times still had a growing industry to absorb them in its expansion cycles, the new hordes of people without work can no longer count with this same horizon. As Jameson notes, this does not mean that this increasingly unemployable surplus population is "falling out" of the capitalist system: they remain a crucial part of the dynamic not only through informal and sub-employment or through the help of credit and social programs, which qualify them as consumers of the ever-growing commodities flooding the market, but also as a social pressure which conforms active labour force to their commodified status.

In short, the crisis of value entails an inversion in the relation between employment and unemployment, a shift which is made possible because of the structural relation between active and idle work in the very constitution of the labour-commodity. Now, this transformation affects not only the relation between workers and capitalists-it also affects the structure of the working class. In the previous sections, we saw that the new role of the cultural commons in the production of surplus has led to the constitution of certain immediate ties between cultural workers, due to the particular conditions of intellectual work and cooperation. But we can now place this transformation in context, by considering it together with the new conditions of active and unemployed workers.

Within the horizon of the "society of work", cultural work was not entirely privatized at all, and so it was considered superfluous in a way, while wage-work, directly employed in the production process, was considered by workers and capitalists alike the essential element of economic development. The unemployed counted as potential workers-either to be employed as the industry developed, or in place of someone else. In short, there was material and structural cohesion guaranteeing the social homogeneity of the working class, as its different fractions were "glued" together by the reference to future work. With the collapse of this horizon, however, what we get is not a shift from manual to cultural work as the "essential" component of valorization, and neither do we witness the end of the working class. Instead, we see the constitution of three separate groups which, while remaining essential parts of the production process, have no social cohesion between them-a social class made of "sharp edges". As Žižek writes: 
It is as if the three components of the production processintellectual planning and marketing, material production, the providing of material resources-are more and more autonomized, emerging as three separate spheres. In its social consequences, this separation appears in the guise of the "three main classes" of today's developed societies, which are precisely not classes but three fractions of the working class: intellectual labourers, the old manual working class, the outcasts (unemployed, or living in the slums and other interstices of the public space). (...) The proletariat is thus divided into three, each part played off against the others: intellectual labourers full of cultural prejudices against the "redneck" workers; workers who display a populist hatred of intellectuals and outcasts; outcasts who are antagonistic to society as such (Žižek in Žižek and Douzinas, 2010: 226)

\section{The commons of external culture}

What traits of this fourth antagonism could endow the communist idea with new concrete determinations?

Let us summarize the results of our investigation thus far into a concise table (Table 1), linking the different commons to their corresponding place in the production process, to the form of enclosure which conditions the forced inclusion of these "fictitious commodities" into the market, to the respective contradictions which ensue from these forced enclosures and the social and ideological fragmentation which results from it.

We are using as basis for this table Žižek's division of the commons into four categories, but, as we anticipated, rather than theorizing the new forms of segregation only indirectly, we have tried to construct an alternative approach based on the historical transformations in the role of the "reserve army" of labour.

This has led to the first innovation in our proposal, which is the mirroring of the distinction between internal and external nature into the cultural commons: there are the commons of "internal" culture-that is, the cultural commons which are compossible with an immediate community: the space of those who share similar ideas, who directly or indirectly cooperate in the social production of knowledge, and so on-and there are the commons of "external" culture. What we are seeking to highlight in this way is not the extrinsic externality of the walls that separate people once the handling of social crises brought about by national and international migration, pauperization and misery become a central concern for state power, but the "intrinsic externality" of culture which is lost to everyone as a result of this situation, a dimension of culture whose proper Marxist name is the generic.

The problem of genericity concerned Marx specially in his early "humanist" writings, and these first studies have rightfully been criticized for not considering the capitalist mode of production from the standpoint of value, but rather of property relations (Althusser, 1969: 49-86). It is true that the focus on the relation between the owners of commodities-that is, the focus on private property-rather than on the determinants of commodity exchange often lead Marx's Economic and Philosophical Manuscripts ${ }^{\rho}$ to an exaggerated personalized view of the driving forces of capitalist society and to an excessively romantic view of labour as a promethean power which men could employ in whatever direction they chose, until the historical dominion of private property alienated us from it. This is one of its most famous characterizations:

In creating a world of objects by his personal activity, in his work upon inorganic nature, man proves himself a conscious generic-being (Gattungswesen), that is, as a

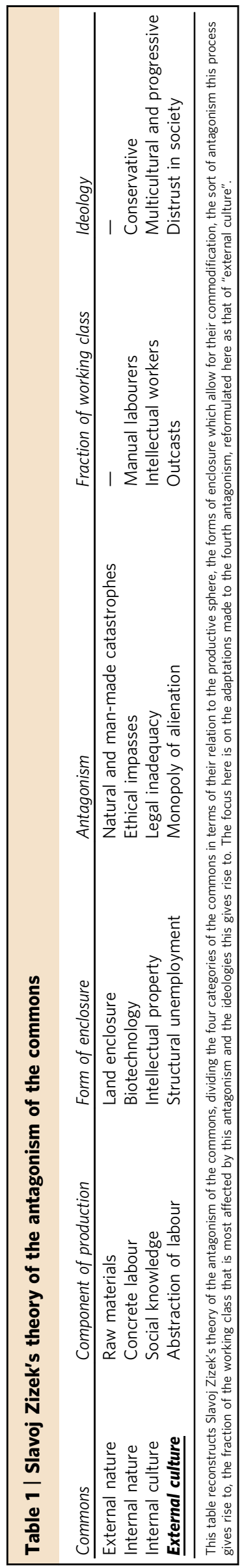


being that treats the genre as his own essential being, or that treats itself as a generic-being. Admittedly animals also produce. They build themselves nests, dwellings, like the bees, beavers, ants, and so on. But an animal only produces what it immediately needs for itself or its young. It produces one-sidedly, while man produces universally. It produces only under the dominion of immediate physical need, while man produces even when he is free from physical need and only truly produces in freedom therefrom. (...) It is just in his work upon the objective world, therefore, that man really proves himself to be a genericbeing. This production is his active generic-life. Through this production, nature appears as his work and his reality. The object of labour is, therefore, the objectification of man's generic-life: for he duplicates himself not only, as in consciousness, intellectually, but also actively, in reality, and, therefore, he sees himself in a world that he has created. In tearing away from man the object of his production, therefore, alienated labour tears from him his generic-life, his real objectivity as a member of the species and transforms his advantage over animals into the disadvantage that his inorganic body, nature, is taken from him (Marx, 1844: 31)

From the standpoint of Capital, this view of man's "generic being" can be criticized in two ways, according to each of the two "entry points" which we previously identified.

From the perspective of the logic of the value-form, Marx's early theory of the generic presents one essential fault: it defines the natural relation of men to their productions and to other men as being one of immediate homogeneity - for I am objectivated in my productions, and, insofar as they attest not only to my own capacities, but also to the capacities of my species, through these productions humanity itself is objectivated and I participate in the transformation of this generic dimension. According to this theory, it is only with capitalism and the reign of private property that this homogenous common background is corrupted and people are confronted with their products and with each other as "alien powers" (Marx, 1844: 32). However, when analysed from the standpoint of commodity-form, this whole presentation appears the ideological naturalization of a homogeneity that was in fact historically introduced with the possibility of formally placing all commodities into equivalence: labouring activities are in fact absolutely heterogenous - there is nothing in common between the different ways one can employ one's concrete energies-it is the commodity-form which homogenizes the products of labour through commodity exchange, ultimately rendering labour itself formally equivalent to its productions. Rather than as a naturally self-transcending capacity, the generic emerges as the social selftranscendence of value, that is, as capital.

If we adopt the second entry point into Capital, the historical analysis of primitive accumulation, the principle defect of the early theory of generic labour is rather assuming that labour is a positive and mobilizable capacity to begin with. As we have seen, the constitution of labour as a commodity is conditioned by the separation of labour time from its employment in a given specific activity: one's labour time must be first unemployed before it can be commodified, that is, employable in whatever function the owner of MP requires it. The negativity which Marx first took as an essential characteristic of man's nature is only conformed to the sphere of labour through a violent historical process of dispossession: man's freedom to produce was historically conditioned by men's "freedom" from means to production.

It is important to note that, when seen from this retroactive perspective, the theory of the generic serves the same role as our critical theory of unemployment: for the "young" Marx, it was the generic capacity of men which connected workers and nonworkers in a social totality-as the human species-and it was this same dormant generic capacity, our "naturally abstract nature", which allowed different human activities to be reduced to a privately owned employable time, no longer freely mobilized by labouring men themselves, but determined by those who buy it.

However, what these two critiques of the generic effectively accomplish is the impediment of any ahistorical, homogenous, unified and positive view of man's capacity for self-transcendence: a historical, heterogeneous, multiple and negative view of human nature remains compossible with the conditions imposed by Marx's later critique of political economy. This is the insight which ultimately justifies thinking of structural unemployment as an enclosure of the "external culture"-that is, a privation of men's capacity to become external to their own cultures. But is it possible to conceive such capacity without the ontological commitments of Marx's original formulation?

Let us briefly analyse the philosophical commitments of Marx's early theory of the "commons of labour" and see if, freed from some of its implicit limitations, we are capable of sketching a new understanding of the generic that is compatible with the categorial critique developed in of Capital.

A noticeable philosophical feature of the theory of generic labour in Marx's writings is the way it mobilizes Hegel's dialectics of realization, that is, the interplay between exteriorization (entäusserung) and estrangement, or alienation (entfremdung) (Hegel, 1977). These two terms define two different ways something can become other to itself: exteriorization implies that what has become other to me remains somehow determined by me-the other and I share a common ground which allows me to recognize myself in it-while estrangement suggests that this common ground itself is interrupted-the other is other to me, that is, it concerns me in a way that is not pure indifference, but I cannot relate to it or recognize my own determinations in it. While exteriorization seems to define our immediate relation to ourselves, for example, when we look at a mirror, estrangement is something more akin to the famous literary figure of the doubleto an image of myself that gains too much autonomy, which escapes my control, but whose actions still refer back to my identity. Consider now this fragment from the above-mentioned quote from the Manuscripts of 1844:

The object of labour is, therefore, the objectification of man's generic-life: for he duplicates himself not only, as in consciousness, intellectually, but also actively, in reality, and, therefore, he sees himself in a world that he has created. In tearing away from man the object of his production, therefore, alienated labour tears from him his generic-life (Marx, 1844: 32)

It is clear that, for Marx, "labour" is defined by the operation of exteriorization, as everything in nature becomes-other to itself without thereby becoming less natural for it. The genericity of man would then derive from the free employment of this natural potency, from the fact we do not only objectivize our natural needs in our productions, but also objectivize ourselves for "the sake of it" - we externalize our very capacity for externalizationwhich is what Marx has in mind when he says that "man, therefore, also forms objects in accordance with the laws of beauty" (1844: 32). And it is this dialectics of externalization which allows Marx to explain the two aspects of capitalist society which, from the standpoint of Capital, would later be conditioned by the structural function of unemployment: the relation between workers and non-workers is explained through the preserved natural bond between man and his species, while the abstract dimension of labour is explained by the fact that out natural 
capacity for externalizing ourselves is not bound to any immediate need in particular. Hegel's theory of estrangement or alienation consequentially reduced to its juridical interpretation, quite possibly due to the critical importance that his Philosophy of Right had for Marx in those years: alienation is only introduced with private property, first as the alienation of the product of man's natural exteriorization, and then as the alienation of the capacity for exteriorization in general, now placed in service of man's animal subsistence.

Let us call the hypothesis of "strong nature", depicted in Fig. 9, the one which considers nature to be essentially elastic (Malabou, 2005: 62). That is, the hypothesis-espoused by Marx in these early writings - that nature only becomes other to itself through exteriorization, requiring an unnatural principle to intervene in order for alienation to occur. Exteriorization is truly an "elastic" operator, since, according to it, nature can always be "stretched" to include whatever becomes other to itself. From the perspective of a strong nature, the constitution of labour as a private property would thus appear as follows:

Nature exteriorizes itself in men, who are other to nature while remaining natural entities. Men, through their natural powers, exteriorize themselves in their creations, which being the expression of men's natural capacities, remain consistent with both the men who immediately produced it, with mankind in general and with nature as such. It is the social relation between men, men relating to each other as others, not as parts of the same nature, which leads the creations of man to become separate from their producers in accordance to a "second nature", that of private property, a logic that alienates man from their creations, and, therefore, from each other and ultimately from natural history itself. The overcoming of the alienation introduced by property relations returns us, finally, to human history conceived as part of the history of the natural world, where our common capacity-our capacity to exteriorize the very power of exteriorization-is collectively assumed.

However, let us now consider an alternative reading. Following a proposal by Adrian Johnston, let us call the hypothesis of the "weak nature" (Johnston, 2013: 5), as depicted in Fig. 10, the claim that nature can be plastic (Malabou, 2005). That is, that nature is incapable of guaranteeing that all that becomes other to nature remains within nature. This is not an affirmative hypothesis, claiming that estrangement is the primary operator of nature, it is rather the much more "humble" proposition that we cannot claim that nature is not susceptible to be transformed in ways that imply the absolute loss of its own initial determinations. As both Johnston and Catherine Malabou brilliantly demonstrate, not only is this hypothesis more compatible with the tenets of dialectical materialism, but it is also much closer to Hegel's own philosophy of nature (Johnston, 2012).

Adopting the hypothesis of a weak nature means, for the theory of the generic, taking Marx's reference to the "duplication" of man in his productions seriously. As we mentioned, for Hegel "entfremdung" is precisely the operation which defines one's relation to a duplicate: the uncanny feeling that somehow we

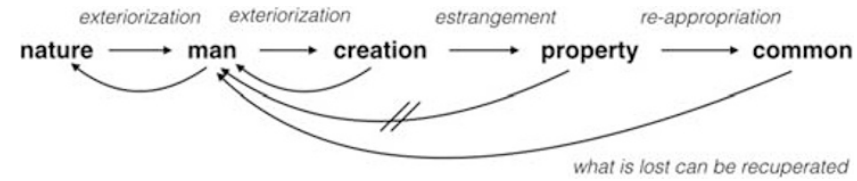

Figure 9 | The hypothesis of strong nature. This schema reconstructs the relations between nature, man and man's productions from the standpoint of the hypothesis of strong nature, that is, the hypothesis that nature is essentially elastic and all alienation must be extrinsic to nature.

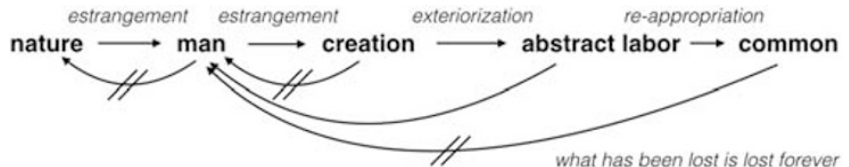

Figure 10 | The hypothesis of weak nature. This schema reconstructions the relations between nature, man and man's productions from the standpoint of the hypothesis of weak nature, that is, the hypothesis that nature is plastic and, therefore, capable of producing, without external influences, creations which are estranged from their origins.

"exteriorized too much", that a quality or essential element which should have remained in the original somehow was passed on to the copy, which all of the sudden confronts us with too much liveliness. In the case of the double, for example, psychoanalysts demonstrate that the uncanny effect they produce does not stem from the likeness of the double to the original, but rather to the fact that the double is more the original than the original man himself (Dolar, 1991; Freud, 2003). Even though this is clearly not what Marx had in mind when he said that, due to our generic capacity we duplicate ourselves "actively, in reality", the adoption of the hypothesis of a weak nature, a nature which is incapable of preventing self-estrangement, leads to theory of the generic that seems to live up to the conditions imposed by its posterior critiques:

Nature becomes estranged in men, not because it has the power to create a powerful copy of itself, a beautiful painting depicting its best traits, but because it is incapable of avoiding the contingent production of a monstrous double, a mirrored image which suddenly gazes back at it. Man thus inherits from nature not a potency, but an impotence: lacking a natural ground, we cannot prevent own productions from acquiring a life of their own, from transcending our purposes and needs with the same indifference and disregard for purpose and utility as man came to look upon the natural world. Furthermore, we cannot prevent our creations from being more "natural" than our own nature: not only becoming other to us, but, through this, becoming in us more than us. From the perspective of "weak nature", the generic emerges not as the positive link that binds men and their creations through a common ground, but as a negative force which denaturalizes us. This is not simply to say that, through our creations, we become different than we are-that is something which the logic of exteriorization can already account for-but rather than we can become indifferent to ourselves: a creation which not only exceeds human nature in its present state, but which, due to nature's plastic character, takes human nature with $i t$, renders the point of view of its maker the inessential and imperfect standpoint.

The hypothesis of weak nature has two immediate benefits. First of all, it is able to account for the division between a "first" and a "second" nature (Gabriel and Žižek, 2009: 95), a division which must be presupposed in the hypothesis of "strong nature". Second, it is compossible with Marx's treatment of privatization and commodification of labour in Capital: as we already seen, it is the commodity form which forces the social recognition between the worker and his productions through a network of formal equivalences, through which one commodity expresses its value in terms of another. And, as it inscribes our self-estrangement into the law of value, we now realize that unemployment is not an enclosure of the generic because it prevents us from expressing our creativity or from participating in the objectivization of human capacity, but because it prevents our "unemployable weakness"-our veritable human nature-from confronting us as an alien force, it prevents us from participating in the accidental production of a standpoint from which we are all equally 
unnatural. The historical, heterogeneous, multiple and negative expression of man's genericity-the sign of its monstrous natural condition-is thus enclosed by being substantialized into an ahistorical, homogeneous, unified and positive commonality, rendering us increasingly deprived of the means to produce something out of the experience of being estranged from each other and from ourselves.

\section{Against the monopoly of alienation}

Alain Badiou developed a theory of "generic procedures", distinguishing different practices in which human activity is capable of exceeding its own cultural limitations: science, art, love and politics (Badiou, 1999). For Badiou, what these different and fundamentally heterogeneous and autonomous fields have in common is that, in all of them, man is pulled out of his own cultural context by his creations-new scientific breakthroughs, new artistic works, love encounters and new political experiments, confronting us with the emergence of previously unthinkable possibilities. But what makes these procedures properly generic is not only that in their novelty they transcendent their context of origin, but rather that they make themselves trans-historically available for others to equally remove themselves from the limits of their own historical situations. A Greek tragedy, for example, remains somehow our contemporary, even though everything from the world in which it was conceived is now gone. And so do scientific conjectures, the stories of love and the egalitarian political experiments: they remain available to us today not because they "captured" the essence of who we are, but because, as proofs of our (in)capacity to remain ourselves, they remain other to us to eternity.

The evocation of Badiou's theory of the generic procedures is useful for us here because it allows us to see how it is that the enclosure of the "commons of external culture" accounts for the absorption of our generic weakness by the vortex of structural unemployment, turning unemployed time into a commodity which can no longer confront us as an alien power, while simultaneously producing a division of social space in which we are never confronted with the limits of our cultural forms of life. This process is highlighted in Table 2 as the monopoly of alienation.

Even though "alienation" has been used as a translation of both Hegel's "entäusserung" and "entfremdung", leading to much confusion in the Hegelian and Marxist literature, by "monopoly of alienation" we mean specifically the monopoly of experiences of self-estrangement: processes whose social efficacy depend on the inversion of the relation between creator and creation (Tupinambá, 2016).

For Badiou, there is a qualitative distinction between the procedures of love, art and science, on the one hand, and that of politics, on the other. While the first three are composed of finite materials-a couple, in love, a sequence of paintings or musical compositions, in art, a set of theorems or experimental protocols, in science-only the political generic procedure is immediately composed by a certain virtual summoning of everyone:

(P)olitics is the sole truth procedure that is not only generic in its result, but also in the local composition of its subject. Only politics is intrinsically required to declare that the thought that it is the thought of all. This declaration is its constitutive prerequisite. All that the mathematician requires, for instance, is at least one other mathematician to recognize the validity of his proof. In order to assure itself of the thought that it is, love need only assume the two. The artist ultimately needs no one. Science, art and love are aristocratic truth procedures. Of course, they are

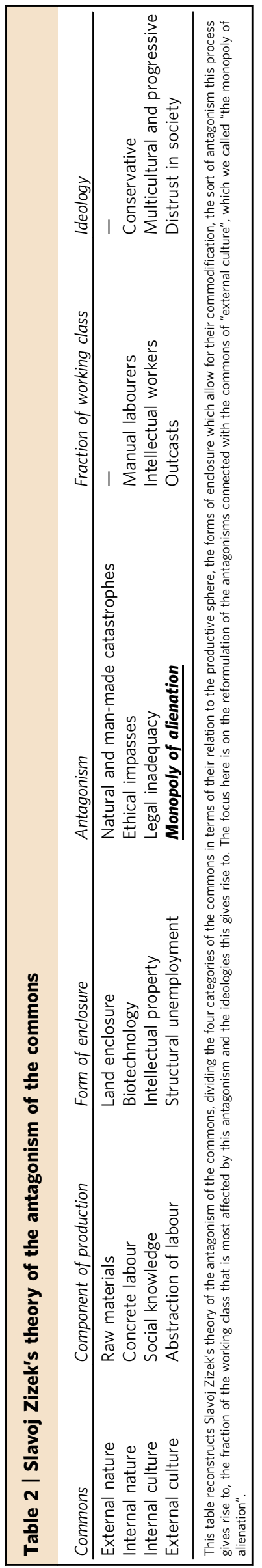


addressed to all and universalize their own singularity. But their regime is not that of the collective. Politics is impossible without the statement that people, taken indistinctly, are capable of the thought that constitutes the post-evental political subject. This statement claims that a political thought is topologically collective, meaning that it cannot exist otherwise than as the thought of all. (Badiou, 2005: 142)

This "qualitative distinction" perfectly mirrors Žižek's remark of the difference between the first three antagonisms of the common and the fourth one, the one of "external culture", and, in fact, allows us to finally draw out one essential trait of this asymmetry: while the commons of nature and internal culture are all commons at the level of consumption-or, as Badiou puts it, are composed of finite material, but "addressed to all"-only the commons of external culture concern the active participation in the production of something that is universal. Which is also why, while science, love and art can continue to exist-even if increasingly constrained to the class of intellectual workers-in a world sinking into barbarism, only the generic dimension of politics is properly impossible under our contemporary conditions. This is not to say that to each antagonism corresponds one of Badiou's generic procedures: rather, this comparison helps us to understand why it is that the more a procedure requires us to access a productive or emancipatory experience of selfestrangement in which the immediate indifference to one another is at play, the less this procedure is available for us today.

Love seems, at least at first, to be the most democratic of the emergences of the generic today, since it is composed of a small number of individuals, inviting them to create an enclosed space of their own, an intimacy, in which cultural differences might have their efficacy suspended (Badiou, 2009: 27-52). Still, as psychoanalysts can surely attest to, while most analysands used to lie on the couch suffering from the impotence of living up to what their lover's expectations, today there is a growing tendency for patients to seek help due to the anguish of not managing to remain sufficiently independent from their partners (Safatle, 2016) - the very estrangement produced by a love encounter with another's desire is subjectivized, more and more, as a violence against one's integrity, an obscene demand that one seeks no longer to answer, but to silence (Badiou, 2009: 5-11).

Art seems to be equally available today-the solitude of the artist, while not generic, like the solitude of lovers, guarantees that art can take place even if there is only one human left alive. However, unlike love, art requires the use of certain formal means, the creation and adoption of rules-rules of composition, procedures to analyse and evaluate a sequence of artistic experiments, and so on-and here we already find that most of us are simply deprived of the access to this formal dimension. This is not to say we are not all welcomed-and, in fact, incitedto express ourselves creatively today, rather, what we witness is that as varied as our forms of cultural expression might be, their common limit is the aversion to any means which would detach creativity from the individual and cultural contexts of which it is the expression (Badiou, 2004: 91). The evaluation of art is dislocated to its capacity to exteriorize its cultural determinants, rather than to transcend them. If this narrows the means for the production of art, on the side of consumption this enclosure of estrangement also makes itself felt. Consider, for example, the veritable incapacity most of us experience when trying to listen to modern musical compositions: though the lack of musical education surely has an important part in how unbearable the experience of listening to Bartok, Berg or Messiaen can be, there seems to be an underlying reason why this lack is not even experienced as such-that is, we simply do not have the subjective means to tarry with the necessary indifference to tonality and to our "natural rhythms" to arrive at the music, simply assuming that the irritating indifference these compositions present to our daily musical environments to mean that they belong to another time and place.

Scientific formalism, on the other hand, does require a really existing community: the repeatability of an experiment or of a proof process is an essential formal component of a scientific breakthrough, and this repetition within different cultural contexts is what demonstrates science's ultimate indifference to any particular world (2004: 79-81). And even though the existence of a scientific community is preserved by the enclosure of the commons of internal culture-as we analysed the social role of knowledge in contemporary capitalism - we are faced with a growing disjunction between science's ubiquitous existence in our lives and our vanishing capacity to even experience this infrastructure as scientific: while technological advances reach beyond what any of us could anticipate-truly exciting the imagination of Marxists who see in this the increase in humanities "productive forces"-our capacity and interest for understanding how technology works, to relate to it not as users, but as producers, decreases in vertiginous velocity (Badiou, 2007: 165).

Finally, this leads us back to politics, and to our concluding remarks.

Nowhere as in political organization-that is, in that singular sort of experience which departs from the affirmation that equality is possible for everyone-is the lack of an access to selfestrangement more immediately present. First of all, as a lack of critical tools: as a brief overview at the history of Marxism will attest to, we simply have not developed the conceptual resources to analyse our own historical experiments in terms of their genericity or self-estrangement. This is quite understandable: the bases of Marxism were all historically established while the horizon of the "society of work" was still supported by capitalist dynamic of accumulation (Postone, 2009: 7), which is why a theory of labour based on the hypothesis of a "strong nature"that is, based on the principle that what is human should always be recognizable as human-made it both irrelevant and impossible to construct a view of our own organizations in which their eventual autonomization from their original political purposes was not conceived a priori as a "detachment from its social bases" or as "bureaucratization". Because of this conceptual deficit, our own critical account of the astounding social catastrophes brought about by the first large scale communist experiments remains hindered: while some of us are still incapable of distinguishing the terror of nazi-fascism's success from the terror of the soviet's failure, most of us have only managed to explain the political "clinamen" that leads from Lenin to Stalin by referring to the latter's almost inhuman capacity to singlehandedly alter the course of history (Žižek, 1989; Hamza and Tupinambá, 2016).

But this incapacity to theoretically assume self-estrangement as an ambivalent force does not only show itself when we consider the past, it is also an essential characteristic of the practice of collective organization today. Just as in the case of art-in which everything is permitted, as long as what is created remains connected to its creator-political practice today is polymorphous and multiple: the political scene is composed of party politics, both in its electoral and its revolutionary forms, social movements of different degrees of institutionalization, different forms of protest and direct action, occupations of land and public areas, and so on, but what is equally excluded from all of them is the wager that discipline can be a tool for political emancipation. By "discipline" we do not mean mere rule-following-even though that is what we usually understand by the term-but rather the following of rules which ourselves have chosen to adopt, or, in 
other words, the subjection to a created rule of which we are in fact the sovereign creators. This definition highlights how discipline requires a form of self-estrangement, since we must trust the application of a formal principle, created in a given context, beyond the limits of that context.

Two things seem to prevent the alienation in a political rule from being experienced as a source of emancipation. First, political processes which constrain themselves to their own fragment of the working class never face the need for enduring the externality of their own culture, since within these different segments some level of social homogeneity is already guaranteed by the state and by communitarian values-in short, political experiments which truly test their concrete claim universality rarely take place. Second, just in the case of artistic and mathematical formalisms, the formal dimension of politics has become almost subjectively unbearable: even though we are used to thinking that what corrupts political experience are the psychic, moral and personal effects of social inequality, the experience of collective political organization clearly shows that it is the experience of equality which is truly anguishing (Žižek, 2012: 963-973). The artificial creation of a space in which the real equality of all is affirmed, a practical affirmation maintained through practical formalist protocols which render militants indifferent to their social, economic and identificatory markings, increasingly wounds our sense of self, often leading to the development of the crudest of psychopathological responses (Lebrun, 2008).

All of this leads us to formulate the hypothesis that the main presentation of the antagonism of the commons of "external culture" today is not the concrete division of our social space, but rather the monopoly of the "empowering" dimension of social alienation in the hands of the managers and technicians responsible for keeping already existing social structures in place today (Invisible Committee, 2014: 28-29). The premise, accepted by Leftists and conservatives alike-though to the benefit of the latter-that alienation is always an oppressive and treacherous force, ultimately antithetical to our human nature and freedom, constitutes a sort of subjective enclosure, the deactivation of the political potential of certain formal tools which have the vocation of exposing us to our own inhuman excess, which Marx called our generic-being and whose "unemployable" quality is equally subtracted from value, property and communitarian relations.

Marx and Engels famously wrote in the German Ideology ${ }^{10}$ that "the ideas of the ruling class are in every epoch the ruling ideas" (Marx and Engels, 1846: 21). Perhaps, when considered from our current perspective, this slogan could be given a new reading. For ideology is not simply the process of assumption of an ideal that is overdetermined by the social situation, but also an operation through which we are brought to abdicate from certain aspects of social reality-among them, tools for effective social transformation-which, rejected in the name of preserving one's identity, become the exclusive property of our political adversaries. In this sense, the proposition that the "ruling ideas are those of the ruling class" does not state that certain ideas rule over us because they inherently reflect the interests of the ruling class, but rather that the ruling class has the monopoly of ideas which have the power to rule over social processes-that is, those practices which concern the transformation, construction and maintenance of a social order.

The very fact that the struggle against the enclosure of the commons of external culture can only be practically conducted through concrete political experiments, whose genericity is only truly put to the test if the formal force of collective organization is capable of extending itself to those walled-off places excluded from the capitalist forms of social reproduction ${ }^{11}$, seems to endow the communist hypothesis with a possible historical and concrete determination.

\section{Notes}

1 Marx, K. and Engels, F. (1848) Manifesto of the Communist Party Available from: https://www.marxists.org/archive/marx/works/1848/communist-manifesto/ch03.htm (5 March 2017).

2 This philosophical movement is composed mostly of authors who propose confrontations between classic and modern systematic philosophy, on the one hand, and post-structuralist continental thinking, on the other: Giorgio Agamben, Alain Badiou, Slavoj Žižek, Jean-Luc Nancy, Jacques Rancière, Gianni Vattimo, Étienne Balibar, Antonio Negri, Kojin Karatani, to quote a few. Most of them have participated in the itinerary conference cycle organized by Slavoj Zizek and Alain Badiou, The Idea of Communism ( Žižek and Douzinas, 2010; Žižek and Badiou, 2013; Žižek and TaekGwang Lee, 2016)

3 Preface in Marx, K. (1859) A Contribution to the Critique of Political Economy. Available from: https://www.marxists.org/archive/marx/works/1859/critique-poleconomy/preface.htm (5 March 2017).

4 For an overview of the theory of the crisis of value, please see the dossier on "Marxism and the Critique of Value", edited by Meditations: Journal of the Marxist Literary Group. Available from: http://www.mediationsjournal.org/toc/27_1.

5 Marx, K. (1867) Capital, volume I, Book One: The process of production of Capital. Available from: https://www.marxists.org/archive/marx/works/download/pdf/Capi tal-Volume-I.pdf (5 March 2017).

6 Marx, K. (1857-61) Grundrisse: Foundations of the Critique of Political Economy. Available from: https://www.marxists.org/archive/marx/works/1857/grundrisse/

7 Kurz, R. (2014) "The Crisis of Exchange Value: Science as Productive Force; Productive Labor and Capitalist Reproduction, Meditations, Volume 27, Nos. 1-2. Available from: http://www.mediationsjournal.org/toc/27_1.

8 Our reading of the role of unemployment in contemporary capitalism was specially influenced by the work carried out by the Endnotes collective (www.endnotes.co.uk) and the journal Viewpoint (https://www.viewpointmag.com).

9 Marx, K. (1844) Economic and Philsophic Manuscripts of 1844. Available from: https://www.marxists.org/archive/marx/works/download/pdf/Economic-Philo sophic-Manuscripts-1844.pdf.

10 Marx, K and Engels, F. (1846) The German Ideology. Available From: https://www. marxists.org/archive/marx/works/1845/german-ideology/index.htm (5 March 2017).

11 An exemplary study in this direction is Bue Rübner Hansen's Surplus Population, Social Reproduction and the Problem of Class Formation published in Viewpoint Magazine-https://www.viewpointmag.com/2015/10/31/surplus-population-socialreproduction-and-the-problem-of-class-formation/ (15 June 2017).

\section{References}

Althusser L (1969) For Marx. Penguin Press: Westminster.

Anderson B (2006) Imagined Communities: Reflections on the Origin and Spread of Nationalism. Verso: London.

Badiou A (1999) Manifesto for Philosophy. SUNY Press: New York, NY.

Badiou A (2004) Infinite Thought. Continuum: London.

Badiou A (2005) Metapolitics. Verso: London.

Badiou A (2007) The Century. Polity Press: Cambridge.

Badiou A (2009) In Praise of Love. The New Press: New York, NY.

Badiou A (2010) The Communist Hypothesis. Verso: London.

Bosteels B (2014) Actuality of Communism. Verso Books: London.

Buck-Morss S (2002) Dreamworld and Catastrophe: The Passing of Mass Utopia in East and West. MIT Press: Cambridge.

Caffentzis C (2013) In Letters of Blood and Fire. PM Press: Oakland.

Dolar M (1991) "I shall be with you on your wedding-night: Lacan and the uncanny" in October, 58, 5-23.

Dupuy J-P (2013) The Mark of the Sacred. Stanford University Press: Stanford.

Ellerman D (1997) The Democratic Corporation. Xinhua Publishing House: Beijing.

Engels F (2001) Socialism, Utopian and Scientific. Electric Book Co: London.

Engels F (ed) (1888) Capital, volume III. Available from: https://www.marxists.org/ archive/marx/works/download/pdf/Capital-Volume-III.pdf, accessed 5 March 2017.

Fourier C (2007) Selections from the Works of Fourier. Kessinger: Montana.

Freud S (2003) The Uncanny. Penguin Classics: Westminster.

Fumagalli A and Mezzadra S (2010) Crisis in the Global Economy. Semiotext(e): Los Angeles, CA.

Gabriel M and Žižek S (2009) Mythology, Madness adn Laughter: Subjectivity in German Idealism. Continuum Press: London.

Graeber D (2011) Debt: The First 5000 Years. Melville House Publishing: New York, NY

Hamza A and Tupinambá G (2016) “The Organization of Defeats" in Crisis and Critique Vol. 3(3). Available from: http://crisiscritique.org/ccmarch/hamzatupinamba.pdf, accessed 5 March 2017.

Hardt M and Negri A (2000) Empire. Harvard University Press: Cambridge.

Hardt M and Negri A (2004) Multitude: War and Democracy in the Age of Empire. Penguin Books: Westminster.

Hardt M and Negri A (2009) Commonwealth. Harvard Press: Cambridge.

Harvey D (2015) Seventeen Contradictions and the End of Capitalism. Oxford University Press: Oxford. 
Hegel GWF (1977) The Phenomenology of Spirit. Oxford University Press: Oxford. Invisible Committee. (2014) To our Friends. Semiotext(e): Los Angeles, CA.

Jameson F (2011) Representing Capital: A commentary on Volume One. Verso: London.

Johnston A (2012) The voiding of weak nature: The transcendental materialist kernels of Hegel's Naturphilosophie. Graduate Faculty Philosophy Journal; 33 (1): $103-157$.

Johnston A (2013) Prolegomena to any Future Materialism, Volume One. Northwestern University Press: Evanston.

Karatani K (2003) Transcritique: On Kant and Marx. MIT Press: Cambridge.

Karatani K (2014) The Structure of World History: From Modes of Production to Modes of Exchange. Duke University Press: Durham.

Kurz R (1994) Der Kollaps der Modernisierung. Reclam: Leipzig.

Kurz R (2014) "The Crisis of Exchange Value: Science as Productive Force; Productive Labor and Capitalist Reproduction, Meditations, Vol. 27, Nos. 1-2. Available from: http://www.mediationsjournal.org/toc/27_1, accessed 5 March 2015 .

Larsen N (2014) Marxism and the Critique of Value. MCM Publishers: Chicago, IL.

Lazzarato M (2015) Governing by Debt. MIT Press: Cambridge.

Lebrun JP (2008) Clinique de l'instituition. ERES: Paris.

Linera AG (2011) Forma valor y forma comunidad. Prometeo: Buenos Aires.

Malabou C (2005) The Future of Hegel: Plasticity, Temporality and Dialectic. Routledge: Oxfordshire.

Marx K (1844) Economic and Philosophic Manuscripts of 1844. Available from: https://www.marxists.org/archive/marx/works/download/pdf/Economic-Philo sophic-Manuscripts-1844.pdf, accessed 5 March 2017.

Marx K (1857-1861) Grundrisse: Foundations of the Critique of Political Economy. Available from: https:/www.marxists.org/archive/marx/works/ 1857/grundrisse/, accessed 5 March 2017.

Marx K (1859) A Contribution to the Critique of Political Economy. Available from: https://www.marxists.org/archive/marx/works/1859/critique-pol-economy/pre face.htm, accessed 5 March 2017.

Marx K (1867) Capital, volume I. Available from: https://www.marxists.org/ archive/marx/works/download/pdf/Capital-Volume-I.pdf, accessed 5 March 2017.

Marx K and Engels F (1846) The German Ideology. Available From: https://www. marxists.org/archive/marx/works/1845/german-ideology/index.htm, accessed 5 March 2017.

Marx K and Engels F (1848) Manifesto of the Communist Party Available from: https://www.marxists.org/archive/marx/works/1848/communist-manifesto/ ch03.htm, accessed 5 March 2017.

Nascimento J (2012) O Avesso do Capital: Ensaios sobre o Direito e a crítica da Economia Política. PerSe Editora: São Paulo.

Negri A (2013) Spinoza for our Time: Politics and Postmodernity. Columbia University Press: New York, NY.

Polanyi K (2001) The Great Transformation, 1st edn, Beacon Press: Boston, MA.

Postone M (2009) Time, Labor, and Social Domination, 1st edn, Cambridge University Press: Cambridge.

Safatle V (2016) Grand Hotel Abyss: Desire, Recognition and the Restoration of the Subject. Leuven University Press: Leuven.

Teixeira R and Rotta T (2012) "Valueless Knowledge-Commodities and Financialization: Productive and Financial Dimensions of Capital
Autonomization" in Review of Radical Political Economics, 44 (4). Available from: http://journals.sagepub.com/doi/abs/10.1177/0486613411434387.

Toscano A (2007) Vital strategies: Maurizio Laxxarato and the metaphysics of contemporary capitalism. Theory, Culture \& Society; 24 (6): 71-91.

Tupinambá G (2016) Freeing thought from thinkers: A case study. in Continental Thought \& Theory; 1 (1): 156-193.

Van der Linden M (2010) Workers of the World: Essays Toward a Global Labor History. Brill Publishers: Boston, MA.

Vicent J, Cohen J and Cowden M (1991) Abstract Labour: A Critique. Palgrave MacMillan: London.

Weeks K (2011) The Problem with Work: Feminism, Marxism, Antiwork Politics and Postwork Imaginaries. Duke University Press: Durham.

Žižek S (1989) Sublime Object of Ideology. Verso: London.

Žižek S (2009) First as Tragedy, Then as Farce. Verso: London.

Žižek S (2012) Less Than Nothing: Hegel and the Shadow of Dialectical Materialism. Verso: London.

Žižek S and Milbank J (2011) The Monstrosity of Christ: Paradox or Dialectic?. MIT Press: Cambridge.

Žižek S and Douzinas C (eds) (2010) The Idea of Communism, 1st edn, Verso: London.

Žižek S and Badiou A (ed) (2013) The Idea of Communism, Vol. 2: the New York Conference. 1st edn, Verso: London.

Žižek S and Taek-Gwang Lee A (ed) (2016) The Idea of Communism, Vol. 3: the Seoul Conference. 1st edn, Verso: London.

\section{Data availability}

Data sharing is not applicable to this article as no datasets were generated or analysed during the current study

\section{Additional information}

Competing interests: The author declares that there are no competing financial interests.

Reprints and permission information is available at http://www.palgrave-journals.com/ pal/authors/rights_and_permissions.html

How to cite this article: Tupinambá G (2017) The unemployable and the generic: rethinking the commons in the communist hypothesis. Palgrave Communications. 3:17073 doi: 10.1057/palcomms.2017.73.

Publisher's note: Springer Nature remains neutral with regard to jurisdictional claims in published maps and institutional affiliations.

(c) This work is licensed under a Creative Commons Attribution 4.0 article are included in the article's Creative Commons license, unless indicated otherwise in the credit line; if the material is not included under the Creative Commons license, users will need to obtain permission from the license holder to reproduce the material. To view a copy of this license, visit http://creativecommons.org/licenses/by/4.0/

C) The Author(s) 2017 